\title{
The Defense Lawyer in the Scales of Chinese Criminal Justice
}

\section{Hou Shumei and Ron Keith*}

Western critics are keenly interested in the defense lawyer as an advocate within the human rights movement in China and fear that under the impact of state persecution the defense lawyer is becoming an "endangered species". This article argues that, while there are significant problems, there is also progress in Chinese lawyering reform that ties together greater professionalism with new emphasis on due process. The revised Lawyers' Law of 2007 is an important new benchmark in lawyer reform. This Law has challenged the limited dimensions of earlier reform. This Law, itself, has been challenged in bureaucratic resistance that is deploying outdated criminal procedural law to negate the reforms supporting new process and protected lawyer-client relations. The National People's Congress has supported the latter arguing that it represents the latest in reform and is, therefore, superior to the more restrictive provisions of the 1996 Criminal Procedural Law and supporting public security regulation.

While Western human rights critics continue to criticize Chinese criminal justice for its negation of due process, internal Chinese debate is focusing on the balancing of society's and the individual's interests in criminal justice. A key component of related reform is who is the "lawyer" and what does he or she do. The critics have, however, claimed that the Chinese

\footnotetext{
* Hou Shumei is a China lawyer, a leading PRC authority on administrative procedural law and a Research Fellow at Griffith Asia Institute, Griffith University. Ronald C. Keith has authored related books such as China's Struggle for the Rule of Law and New Crime in China: Public Order and Human Rights. He is Professor of China Studies, International Business and Asian Studies at Griffith University. This article is based on the revision of a paper presented to the July 2009 panel on Chinese criminal justice at the Australian China Studies Association. The authors thank the reviewers at the Journal of Contemporary China for helpful comments. The authors can be reached by email at s.hou@griffith.edu.au
} 
defense lawyer is becoming an "endangered species". ${ }^{1}$ This article examines the contradictions of lawyering reform in China. The National People’s Congress (NPC) has stated that the 2007 revised lawyer is superior to the 1996 Criminal Procedural Law (CPL). ${ }^{2}$ This article asks whether legal reform is moving towards a new paradigm focusing on the professionalism of the lawyer as a trained and certified "practitioner" who works for a law firm, is a member of a Law Association and is able to use due process to protect his or her client.

Lawyering reform has to be placed in historical context. In imperial China there was no "species" of lawyer to endanger. The first generation of "lawyers" really only emerged in the 1960s, and they were mainly part-time "state workers". Even as state workers, they went to ground during the Cultural Revolution. Early 1980s lawyer reform, however, embraced a new "balance of values". This gave some new formal recognition to the procedural protection of the rights of the accused; however, in practice, society's concerns over the spread of violent crime received much greater attention. ${ }^{3}$ At this point the lawyer was still a "state worker" legally required to put society's interests ahead of those of the client. The "balance" was still skewed in the 1996 lawyer reform, but the latest 2007 amended lawyer's law placed more robust emphasis on the lawyer's professional defense of client rights.

This latest reform has been difficult to implement due to pervasive bureaucratic resistance within the judicial process that often prefers to stick with the older provisions of the 1996 Criminal Procedure Law (CPL) and supporting public security regulations. Different players in the criminal judicial system use different rules to achieve their competing goals.

\footnotetext{
${ }^{1}$ This term is used in a quoted Epoch Times interview, “The Perils of China's Lawyers,” The Journal of Human Rights in China, 2, (2000), p.1, and pp. 34-39.

${ }^{2}$ Legal Work Committee, National People’s Congress Standing Committee, Dui zhengxie shiyi jie quanguo weyuanhui diyici huiyi di1524hao (zhengzhi falulei 137 hao) ti an de dafu, (Reply to politics and law proposal 137 from the Chinese People’s Political Consultative Conference Session 1524), (15 August 2009).

${ }^{3}$ The notion of a "balance of values" pervades Chinese jurisprudence. See Ronald C. Keith and Zhiqiu Lin, Law and Justice in China’s New Marketplace (London \& New York: Palgrave Press, 2001), pp. 23-7.
} 


\section{Western Interpretation of China Lawyer Reform}

What does the Western scholarly literature already tell us? There is an extraordinary mix of optimism and pessimism. In 1997 Ronald Brown referred to the changes in the functions of lawyers and judges and professed a certain admiration: “...all critical legal personnel and key legal institutions are now being upgraded both as to personnel qualifications and standards of performance...the new legal system which has emerged only since 1979, after the ravages of the Cultural Revolution, is nothing less than amazing..."4

Writing in 2004, Albert Chen, described a change in the system from “one dominated by the government to one in which rule-making and regulatory powers are shared between the government and the legal profession.” Chen was disappointed in the limitations of the $1996 \mathrm{CPL}$ as it related to the protection of rights, but he still referred to a "paradigm shift": "As official thinking about lawyers changed, the system of regulation of lawyers and their professional conduct also underwent a paradigm shift." 5 Randall Peerenboom, referred to "partial independence" noting that the lawyers were achieving increasing independence from the Ministry of Justice(MOJ) and that the 1996 Lawyers Law had redefined lawyers "in a much less politically charged way.”6 Jianfu Chen wrote that the 1996 Law had "consolidated the various reforms undertaken in the 1980s and 1990s and has since changed the nature of the legal profession in China” as Chinese lawyers are now “allowed by Chinese law to perform similar functions to those of lawyers in other countries.” Chen affirmed: “Although lawyering in China

\footnotetext{
${ }^{4}$ Ronald Brown, Understanding Chinese Courts and Legal Process: Law with Chinese Characteristics (The Hague: Kluwer Law International, 1997), p. 28.

${ }^{5}$ On professional self-regulation see Albert Chen, An Introduction to the Legal System of the PRC, $3^{\text {rd }}$ edition, (Hong Kong, Singapore, Malaysia: LexisNexus, 2004), p. 176.

${ }^{6}$ Randall Peerenboom, "Law enforcement and the legal profession in China” in Jianfu Chen, et al., Implementation of Law in the PRC (The Hague: Kluwer Law International, 2002), p. 133
} 
is not deemed to be a 'free profession', today's lawyers are increasing independent and willing to take on the state.”

In his 2007 China Quarterly article, Benjamin Liebman, observed: “Depoliticization—to the degree it has occurred-- may be possible precisely because the courts are not a challenge to Party authority.” ${ }^{7}$ In a 4 September 2007 e-mailed memorandum to its clients Fried, Frank, Shriver and Jacobson LLP approvingly cited the Ministry of Justice's (MOJ) role in the drafting of the amended 2007 version of the Lawyer's Law. Although the MOJ's position as an “executive arm of the government” was recognized, the Ministry was commended for vetting a stronger amendment highlighting the self-regulation of lawyers by their respective law firms. ${ }^{8}$

Human Rights Watch (HRW) has been more negative both as to the substance of the amended Lawyer's Law and to the role played by the MOJ. The HRW's reporting is especially concerned with the state persecution of lawyers involved in China's human rights movement. The HRW April 2008 report considered the 2007 revision to the Lawyer's Law and concluded that, despite some new positive elements, nothing had really changed, that lawyers were still at the mercy of state persecution, that if anything the control and intimidation of lawyers was increasing, and that the MOJ, itself, has been complicit in this intimidation. The report's assumption that the CPL takes precedence over the Lawyer's Law in the case of conflict is arguable in light of recent NPC developments. ${ }^{9}$

The above pessimism and optimism reflect different starting assumptions and analytical purpose. The discussion here begins with the study of legal change in China as a complex and unprecedented process. The latter responds to changing and sometimes conflicting institutional

\footnotetext{
${ }^{7}$ Benjamin Liebman, “China’s courts: restricted reforms,” The China Quarterly, 191, (September 2007$)$, p. 627.

8 “China’s revised lawyer's law: toward a strengthened legal profession,” (4 September 2007), available at: www.friedfrank.com, accessed on 1 September, 2009.

${ }^{9}$ Human Rights Watch, "Walking on Thin Ice": Control, Intimidation and Harassment of Lawyers in China. New York, NY, 2008, p. 13.
} 
bias and socio-legal norms that reflect the interaction of domestic preferences, often labeled as "Chinese characteristics", with international legal norms, concepts and practice. The "rule of law" has no real basis in the Chinese tradition and yet the state constitution was amended in 1999 to support a Chinese socialist rule of law. Human rights” were endorsed in an amendment in 2004. More recently, however, there appears to be a re-emphasis on "Chinese characteristics" in the legal system. ${ }^{10}$

The current readjustment reflects deeply embedded values and institutional patterns. For a long time courtroom practice has exclusively reflected the features of the inquisitorial system that placed society's interest above that of the accused:

The judge, in this system, not only moderates issues of trial procedure, but also actively seeks the 'truth' in the case. The judge can jump over the defense, make investigations, and examine witnesses. The defendant all the while is unable to claim the right to silence, is unable to call and cross-examine a full range of witnesses, and is subjected to rounds of questioning from the judge, the public prosecutor as well as from the victim. The Procurator, on the other hand, not only prosecutes the defendant, but she/he is also responsible for the integrity of trial procedure. This is not to mention the practice where by the procurator deliberately fails to provide the defense with full disclosure of the evidence. $^{11}$

The 1996 CPL initiated reform that converged with the largely foreign assumptions of the adversarial, as opposed to the inquisitorial system. Traditional "judicial integration," as

\footnotetext{
10 For example, see Hu Jintao, "Lizu Zhongguo tese shehuizhuyi shiye fazhan quanju, zhazha shishi kaichuang woguo zhengfa gongzuo xin jumian”, (Based on the overall development of socialism with Chinese characteristics consolidate a new prospect for political and legal work in China), 25 December 2007 speech at the national conference of political and legal work available at http://paper.com.cn/rmrb/htm1/200712/26/cobntent_35370694.htm, accessed on 7 September 2009.

${ }^{11}$ Ronald C. Keith and Zhiqiu Lin, New Crime in China: Public Order and Human Rights. (London and New York: Routledge [Taylor \& Francis Group], 2006), p. 160.
} 
predicated in the "umbrella theory" was challenged by "triangular theory" (sanjiaoxing) that presumes that the judge is to act more like an umpire who treats the defense and the procuratorate with impartial equanimity. There are conflicting adversarial and inquisitorial elements within China's framework of criminal justice. The reform of Chinese criminal justice is a work in progress. The deliberately formal, not to mention the informal process synthesizing "localization" and "internationalization" in the context of China’s legal reform is not easy to track given competing jurisprudential assumptions, the incoherent hiatus between theory and practice and the frequent changes in the practice of law and policy. And of course all of this is taking place within an extraordinary dynamic era of societal and institutional change that reflects the profound structural transition from a planned to a market economy.

The analysis herein is mindful of the more general context, discussed above, but it focuses on the changes that were ushered in with the amended lawyer law of 2007. The analysis highlights controversial changes that feature the relative independent professional status of, and the protection of, the rights of criminal law lawyers as they attempt to execute their duties to protect their clients. The 2007 law has encountered turbulence as bureaucratic resistance is resorting to conflicting CPL provisions and regulated provisions so as to thwart the implementation of the 2007 reforms.

\section{Contextualizing the Struggle for the Lawyer's Independent Professionalism}

The above analysis identified a problem of history that suggests that China's "lawyers" are on their own bitter "Long March" as they struggle with a deeply entrenched bias. Contemporary lawyer reform, particularly as it connects with the application of due process, has very little basis in Chinese history and society, and the lawyer, as "lawyer" has truly had to struggle hard for recognition today’s China. 
The "lawyer" did not exist in imperial China. There were, however, publicly despised scribes, or “litigation sticks”(songgun or songshi). ${ }^{12}$ These scribes manipulated all parties to stir up litigation. Specious accusation dripped from their brushes, hence the songshi were the "evil gods of the knife-pen” (daobi xieshen). ${ }^{13}$ In the interest of harmony, the imperial system tried to $r$ the suppress tendencies to litigation; for example, the Emperor Kangxi's 1760 Sacred Edict or Sheng yu admonished his subjects "to prevent quarrels and litigation.” ${ }^{14}$ Criminal law was a necessary administrative backstop, but it was denied any independent standing. For the officials who were by extension the parents of the people, querulous litigation was a politically inconvenient sign of disharmony.

In Europe "lawyers” were "gentlemen of the robe” (noblesse de robe) who who dedicated the "pen” in the service of royal government. The Confucian "gentleman” (junzi), on the other hand, looked down on Legalists who used law as a poor substitute for moral example and action. The Confucian "royal way" was based upon "sageliness within” and the demonstration without of official moral behavior in the family and society. The Chinese tradition did not generate any equivalence to professional legal development in Europe, hence there was no virtuous class of legal honoratiores as described in Weber's sociology of law. ${ }^{15}$

Essentially, the lawyer system came into China from the West. The notion of "lawyer" only became possible in the late Qing when the jurist, Shen Jiaben, drafted the Great Qing Dynasty Criminal and Civil Procedural Law. This 1906 law referred to the lawyer's registration, qualifications and duties; however, it was only episodically applied in practice. Under the

\footnotetext{
${ }^{12}$ Wang Di, “Cong songshi dao lushi-tan woguo jindai lushi zhidu de chansheng ji fazhan” (From the songshi to the lawyer-discussing the creation and development of China's modern lawyer system), Shangye Wenhua (Business Culture) 11, 2008, p. 205.

${ }^{13}$ Albert Chen, An Introduction to the Legal System of the PRC, $3^{\text {rd }}$ edition, p. 164.

${ }^{14}$ John k. Fairbank, E.O. Reischauer and A.M. Craig, East Asia: The Modern Transformation (Boston: Houghton \& Mifflin, 1965), p. 85.

${ }^{15}$ Max Weber, Economy and Society. Edited by Guenther Roth and Claus Wittich. (Berkeley: University of California Press, 1968), pp. 784-795.
} 
warlord-president, Yuan Shikai, the Beijing government approved The Temporary Regulations on the Lawyers in $1912 .{ }^{16}$ The subsequent Guomindang government assigned a low priority legislation on lawyering. Essentially, these were humble beginnings, and the legal system lost any semblance of coherence in the context of warlordism, Japanese invasion and civil war. ${ }^{17}$

In post-1949 China the status of lawyers was undermined in cycles of unpredictable class struggle. As of the promulgation of the 1954 State Constitution there were only 3000 lawyers. The Constitution endorsed equality before the law and referred to the defendant's right to procedural justice, but in the 1958 Anti-Rightist Campaign the lawyer was accused as "capitalist element" who stood in the way of mass justice. In the Cultural Revolution the entire judicial process was hit with accusations of capitalist restoration. Rival mass organization set up kangeroo courts to bring the bowed class enemy before the enraged masses. "Legal nihilism" prevailed. The masses took justice into their own hands calling for the three smashes (sange zalan), smashing public security, the procurotorate and the people's court. The law and legal process had become a discredited refuge for capitalists and counterrevolutionaries.

Prior to 1979, the criminal law was viewed as the state's weapon that was to be wielded against criminal elements. Criminal law supported the political calculation underlying "strike hard" (yanda). Severe punishments were doled out on the basis of "execute one to warn a hundred” (sha yi jing bai). ${ }^{18}$ No one dared defend the rights of the accused class enemy and the changing politics of class struggle freely ran though the criminal law generating different degrees of politically determined punishment in different periods and places for the commission of the

\footnotetext{
${ }^{16}$ Zhao Chaoqin, "Zhongguo lushi zhidu yuanyuan yanjiu," (Research on the time when the lawyer appeared in China)," Henan jingguan xueyuan xuebao (Journal of Henan Police Officials College), 3(1), (March, 2005), pp.106110,

${ }^{17}$ Ibid.

${ }^{18}$ Ibid., pp. 146-7.
} 
same crime. ${ }^{19}$ Criminal justice was less predictable and fair than impossibly flexible and politically capricious. The "feudal" dimensions of authority were seemingly reinforced in the purposes of the modern Party State. "Feudalism” or tradition had asserted that "ethics and law are inseparable” and Chinese Marxism-Leninism placed criminal justice firmly within the unity of state administration so as to guarantee the dictatorship of the proletariat.

In September 1979 the Ministry of Justice was re-established. It issued the 9 December 1979 notice reinstating the lawyer system. The number of lawyers had declined to a mere $212 .{ }^{20}$ In the early 1980s Deng Xiaoping's legal reforms included the 1980 promulgation of provisional regulations on lawyers and a new remedial emphasis on the procedural protection of individuals against arbitrary accusation such as had occurred in the Cultural Revolution. The law became part of Deng's new institution building strategy to ensure political and social stability. The dynamics of economic reform helped create the need for lawyers, but the lawyer's prestige did not automatically rise. The public loathed lawyers who were involved in the corruption that accompanied unregulated reform. Indeed some lawyers would do almost anything to cultivate clients for the sake of extravagant fees exorbitant profit. They were viewed by their colleagues as “wild lawyers”( yelushi). Such a sentiment is a problem even today as discussed below with the Li Zhuang case.

In the early reform context "lawyers" were still categorized as "state legal workers" (falu gongzuo zhe)”. They were obliged to help maintain public order on the basis of officially prescribed morality. If they failed to uphold society's interests over those of their clients they faced the loss of their credentials and/or criminal law punishment. Thus lawyers were tolerated,

\footnotetext{
${ }^{19}$ Ibid., p. 154.

${ }^{20}$ Liu Guiming: Zhongguo lushi zhidu huifu chongjian 30 nian zhong de 10 ge zhongyao shike( Lui Guiming: 10 important events in the last 30 years of re-establishing China's lawyer system), interviewed by Hu Yongping, available at http://www.china.com.cn/news/2009-04/17/content_17625905.htm accessed on 27 January 2010.
} 
but not celebrated. It was difficult properly to defend clients when there was such a heavy onus on the lawyer to act so as to give priority to the state's goals of public order based on strong law enforcement.

Legal reform that started in December 1978 precipitated qualitative changes over time. In 1986 the Judicial Examination System for Lawyers was set up and the All China Lawyer's Association was established. With deepening economic reform, the law was hailed as a rational affair that reflected a new principle of legality that eventually coincided with a new reference in the 1990s both to accelerated economic reform and to the protection of human rights through due process. As the state plan gave way to the "socialist market", the lawyer's system underwent a structural revolution. In 1988 most state-owned law firms became cooperative law firms and then in 1993 most cooperative law firms became private partnerships. In 2000 most of the remaining state-owned law firms were required to transform into private partnerships. ${ }^{21}$

This organizational change did not spell an end to Party influence within lawyer organization but it was intended to move beyond the singular focus of the state worker to support a trend toward new professionalism consistent with international norms and standards. Reform achieved a victory at least in terms of form, if not always in practice, with the major revision to the CPL in 1996. The then Minister of Justice, Xiao Yang explained the significance of the revision:

The recent amendment of the Criminal Procedure Law has...scientifically embodied the dialectical relationship between punishment of crime and protection of citizen's rights. ...this amendment conforms to international practice and commonly observed

\footnotetext{
21 "Zhongguo lushi zhidu fazhan licheng" (The historical development of the lawyer system), The 2007 Lawyer Law in its Articles 15, 16, and 20 later acknowledged not only partnership firms, but also new firms set up by single lawyers and national law firms financed by the state, available at:

http://www.sg148,com?Article/Showinfo.asp?InfoD=922, accessed on 1 September, 2009.
} 
judicial principles; and therefore proves beneficial to a strict enforcement of the law, to the protection of human rights, and to our efforts to reinforce out international cooperation and struggle in the fields of jurisprudence and human rights. ${ }^{22}$

Indeed this reform highlighted equality before the law, no crime without a law and no punishment without a crime, and the punishment must fit the crime” (zuixing yizhi) that expressly opposed "heavy-penalty-ism" (zhongxingzhuyi) and the exclusive focus on law as a matter of deterrence without reference to the protection of rights.

The 1996 CPL revision was a rushed affair, but it began to address the reform of trial proceedings and to revise the right to counsel. Lawyers were still admonished to ensure the public good, but Chinese jurists acknowledged that the earlier 1979 CPL trial system invariably produced guilty verdicts. "Decide first, trial later" had undermined the credibility of criminal justice. Over Public Security opposition the NPC in 1996 built upon the "SPCC Opinion for the Proceedings of First Instance in Cases involving Public Prosecution” (30 November 1992) that had sought to qualify the inquisitorial role of judges and to "enhance the defense counsel's role in the protection of the rights and interests of the accused and to shift the judges into a more neutral position between the defense counsel and procurator." ${ }^{23}$ The passage of the newly revised Criminal Law in 1997 called for the comprehensive stipulation of law as opposed to the capricious principle of "flexibility" that had earlier justified "policy as the soul of law". The twin principles of nulla crimen sine lege (no crime without a law) and nulla poena sine lege (no punishment without a law) were asserted to correct past arbitrary state behavior .

Wang Zuofu, an eminent Renda jurist, and Zhang Fengge, Director, Criminal Office of the Supreme People's Procuratorate (SPP) claimed that Chinese reform was reflecting "world

\footnotetext{
${ }^{22}$ Keith and Lin, Law and Justice in China,, p. 185, fn 27.

${ }^{23}$ Ibid., p. 197.
} 
trends” and hailed reform as it “...is conducive to preventing the practice of determining crimes at one's own discretion and has provided more effective legal protection for citizen's personal freedom, rights and interests..... ${ }^{24}$

The then Minister of Justice, Xiao Yang, also eulogized the 1997 Criminal Law as it concerns the balancing of society’s interests with the protection of individuals:

...the principle of convicting a crime and meting out punishment according to the law has replaced reasoning by analogy. This is historical progress symbolizing an important step taken by China in 'running the country according to the law'; and it has as much epochmaking significance as the elimination of determining guilt by presumption of guilt from the CPL. This principle, which can prevent arbitrariness in convicting crime, provides a more powerful legal guarantee for citizens’ personal freedoms and rights, as well as a solid legal foundation for the judicial organ to severely punish crimes and to protect people’s interests according to the law. ${ }^{25}$

The state's past manipulation of the law was addressed in the explanations of reform, and this serves as the background to the 1996 revision to the lawyer's law. Albert Chen cites the latter's historical significance: “The new law abandoned the former conception of lawyers as 'state legal workers' in favor of a new definition of the nature of lawyers in China as 'practitioners who have obtained lawyers' practicing certificates in accordance with the law and provide legal services to society."26 Society is referenced here rather than the clients.

The 1996 Lawyer Law further clarified that in future lawyers would have to be certified and that they would have to pass a national qualifying examination. The same law addressed the creation of law firms and the strengthening of lawyers' associations. The NPC Legal Affairs

\footnotetext{
${ }^{24}$ Keith and Lin, New Crime in China, p. 3.

25 As cited in Keith and Lin, Law and Justice in China's New Marketplace, p. 211.

${ }^{26}$ Chen, An Introduction to Legal System of the PRC, $3^{\text {rd }}$ ed, p. 167.
} 
Work Committee discussed, but the NPC Standing Committee later rejected the idea of partially transferring the responsibility for the disciplining of lawyers from the MOJ to the All-China Lawyer's Association. $^{27}$

In the context of accelerated economic reform, there was strong NPC support for professionalism as reinforced in tighter rules regarding lawyer's qualification; however, some NPC delegates were unhappy with lawyers who were only interested in "hunts for money with great enthusiasm.” ${ }^{28}$ Some delegates wanted more punishment for lawyers who violate the law, but mainstream opinion focused on protecting the lawyers’ rights against interference by any units or individuals.

According to Albert Chen's analysis, the 1996 “paradigm shift” was incomplete. His analysis cited outstanding difficulties in at least four key areas that later became the focus of the 2008 HRW report. The four areas specifically relate to 1) lawyer access to clients 2) the limited lawyer access to materials 3) obstacles to lawyer investigation and the collection of evidence and 5) Criminal Law Article 306 injunction against lawyer destruction or fabrication of evidence, or support for client misuse of such documentation and the coercion or improper inducement of witnesses to bear false testimony. ${ }^{29}$

Similarly, the Lawyers Committee for Human Rights in New York faulted the 1996 Lawyer's Law for failing to converge with UN Basic Principles in the areas of “(i) lawyer's freedom of expression, political ideology and association; (ii) due process concerns in criminal matters and: (iii) the duty of lawyers to uphold human rights and fundamental freedoms

\footnotetext{
27 "NPC Law Committee Head Reports on the Revisions of Draft Laws,” Xinhua, (14 May 1996), FBIS-CHI-96-095, May 14, 1996, p. 21. See Chen's analysis on this in An Introduction to the Legal System of the PRC, $3^{\text {rd }}$ edition, p. 179.

28 “PRC: Legislators Review Draft Law on Lawyers,” Xinhua, Beijing, (5 May 1996), in FBIS-CHI-96-092, 10 May 1996, pp. 18-19.

${ }^{29}$ Ibid.
} 
recognized by national and international law." ${ }^{30}$ The Committee regretted that the failure to use the widely accepted term for lawyers as "free professionals" and objected to emphasis on the lawyer serving society rather than the client. ${ }^{31}$

\section{The Ongoing Stand Off: the 2007 Lawyers Law and the CPL}

Chinese legal reform has formally featured the goals of lawyer professionalism and the improvement of due process. The first article of the 1980 Interim Regulations on Lawyers characterized the lawyer as a "state legal worker" (guojia falu gongzuozhe) who was responsible to protect the interests of the state, the collective and the people. ${ }^{32}$ The amended Lawyer's Law of 1996 featured lawyer professionalism. Article Two stated: "Lawyers mentioned in this law refer to personnel who have obtained a business license for setting up practice of a lawyer in accordance with the law and provide legal services for the public.” The subsequent 2001 amendment to the lawyer's law was a modest reform, but it highlighted the lawyer as a professional who required a certificate to practice law. The 2007 amendment, however, was fulsome in its characterization of the lawyer, as "lawyer". It lifted the status of law firms and introduced important new due process so as to enable the lawyer to focus on the rights of the client. This reform trajectory reflected incoming ideas from abroad.

However, in lawyer reform as in other types of legal reform there have been inconsistencies in legal form and practical application. The state's political interference with applied criminal law has been a longstanding issue. The state in the past easily moved between "heavy penalty-ism" that presumed "a little benevolence towards a crook interferes with the

\footnotetext{
${ }^{30}$ Lawyers Committee for Human Rights, Lawyers in China: Obstacles to Independence and the Defense of Rights, New York, (March 1998), pp. 46-7.

${ }^{31}$ Ibid., p. 50.

${ }^{32}$ Article 1, Zhonghua renmin gongheguo lushi zanxing tiaoli (Interim Regulations of the People's Republic of China on Lawyers), (26 August 1980), available at: http://chinalawlib.com/294939.html, accessed on 30 August, 2009.
} 
great benevolence [owed the people] and politically inspired leniency such as "less killing" (shaosha zhengce). ${ }^{33}$ The dialectical pendulum of criminal law punishment swung back and forth between "severity" and "leniency". The socio-political importance of deterrence and the “transformative function” (gaizao gongneng) of criminal law have long been assumed. The emphasis on the protection of the rights of the accused is of more recent vintage. In spite of, or because of this past, legal reform has called for greater rationality and has had some impact on the ways in which politics have affected court sentences ${ }^{34}$.

Related change is often quixotic. Its content is patently clear in the revised lawyer's law, but related revision was not immediately squared with cognate law and practice, and this gave rise to discrepant and uneven application of the law not to mention confusion in court process and unequal and arbitrary treatment of the lawyer's clients. Sue Trevaskes in her study of the Baotou courts noted the related systemic and value contradictions of Chinese courts:

...criminal court work in Baotou and nationwide was caught between the promises of economic prosperity and threat of instability. This required the criminal courts to be "all things to all people»: an increasingly autonomous and thus increasingly legitimate bastion of "rule of law" values; a simultaneous expression of institutional procedural propriety and a raw expression of state power; .... ${ }^{35}$

China's jurists and jurisprudence are used to juggling such contradictions within a formal "balance of values.”

\footnotetext{
${ }^{33}$ Keith, China's Struggle for the Rule of Law, p. 146.

${ }^{34}$ Although in the early reform the Party signaled its intent to stay our of court sentencing in individual cases, judges have complained about instances where the Party has demanded telephone or written reports by judges on cases of interest. See Xin Chunying, "What Kind of Judicial Power Does China Need," Journal of Constitutional Law, 1, (1), (2003), p. 70.

${ }^{35}$ Susan Trevaskes, Courts and Criminal Justice in Contemporary China (Lanham: Lexington Books, 2007), p. 21.
} 
The 2007 "balance of values" gave new precedence to the lawyer's protection of the client as distinct from the lawyer's responsibility to uphold the public good. The 2007 revised wording of Article Two dropped the 1996 and 2001 admonitions that the lawyer is to act "for the public" but added reference to the "client". The new emphasis is italicized as follows: "A lawyer as mentioned in this Law shall refer to a practitioner who has acquired a lawyer's practicing certificate according to law and accepts authorization or appointment to provide legal services for a client. A lawyer shall maintain the legal rights and interests of a client, maintain the correct enforcement of law, and maintain social fairness and justice."

New Articles 23 and 24 enhanced the position of law firms. Article 23 emphasized the law firm's ability to "supervise its lawyers' compliance with professional ethics.” Article 24 required law firms to provide an annual report to the appropriate level of state justice authority detailing lawyer practice results. Again reform re-jigged the balance of values giving more emphasis to professional self-regulation.

The 2007 revision gave new impetus to professionalism and due process. The internal criticisms of reformers had concentrated on the lawyer's inability to see his or her client before the crucial first interrogation by the procuratorate, reformers were also concerned about access to all of the state's evidence, the intimidating presence of procuratorial and public security functionaries during the first lawyer-client interview and the possibility that lawyers could be subject to frivolous criminal charges for defending their clients too vigorously in court. ${ }^{36}$

Article 32 remained unrevised. It upheld the lawyer's responsibility to refuse representation in light of client propositioning to engage in "illegal activities." However, several

\footnotetext{
${ }^{36}$ Mo Shaoping in his 2005 interview noted that unlike the 1979 Criminal Law, the revised law of 1997 had a provision for "perjury by a lawyer" under Article 306 and that somewhere between 200 and 300 lawyers had been prosecuted under this provision "The Perils of China's Lawyers," The Journal of Human Rights in China, 2, (2005), p. 35.
} 
new articles strengthened the lawyer's independence in protecting the client. The all new wording of Article 33 gave lawyers better access so that the client was not left along before an intimidating “investigative organ”:

As of the date of first interrogation of or adoption of a compulsory measures on a criminal suspect by the criminal investigative organ, an authorized lawyer shall have the right to meet the criminal suspect or defendant and learn information related to the case, by presenting his lawyer's practicing certificate, the certificate of his law firm and the power of attorney or official legal aid papers. A lawyer who meets a criminal suspect or defendant shall not be under surveillance. ${ }^{37}$

The importance of the lawyer's meeting with the client (huijian) on the date of "first interrogation” was reiterated in new wording added to Article 34. This article also deals with the lawyer's right to duplicate litigation documents and case materials. Again the new wording is italicized: "As of the date of prosecution examination of a case, an authorized lawyer shall have the right to consult, extract and duplicate litigation documents and case materials." ${ }^{38}$ The lawyer's ability to see and to collect evidence was strengthened in the new Article 35 that stated: "As needed by a case, an authorized lawyer may apply to the people's procuratorate or the people's court to gather, investigate and take evidence or apply to the people's court for notifying a witness to testify in court.”39

The outstanding issue over the misconstruction of the lawyer's defense remarks at court as "lawyer perjury" was addressed in a new, but still qualified admonition in the greatly expanded wording of Article 37: "The personal rights of a lawyer in practicing law shall not be

\footnotetext{
${ }^{37}$ Article Thirty Three, Law on Lawyers of the People's Republic of China, unofficial translation provided by International Bridges to Justice, available at: http://vip.chinalawinfo.com/newlaw2002/slc/slc.asp?db=chl\&gid=98767, accessed on 30 August, 2009.

${ }^{38}$ Ibid.

${ }^{39}$ Ibid.
} 
infringed upon. The representation or defense opinions presented in court by a lawyer shall not be subject to legal prosecution, however, except speeches compromising national security, maliciously defaming others or seriously disrupting court order." ${ }^{40}$

Essentially, the new Articles 33, 35 and 37 and the amended Article 34 represented formal commitment to substantively new procedural justice. However, the Lawyer's Law was inconsistent with well established procedural law and regulation, and this has resulted in uneven treatment of clients.

\section{Contradictions in Law and Practice}

Article 33 of the 2007 lawyer's law stipulated that the lawyer-client interview could take place "at the date of first interrogation or, or adoption of compulsory measure on a criminal suspect by the criminal investigation organ." The "or" gave the procuratorate extra time to establish their own case without reference to the defense. "Compulsory measures" referred to the formal placing of restrictions on the personal freedoms of the defendant. However, Article 96 of CPL favored the procuratorate indicating that the defense lawyer could only have an interview with the client "after the criminal suspect is interrogated by an investigation organ for the first time or from the day on which compulsory measures are adopted against him....”

As a basic law, the CPL was reinforced by related key regulations; for example, the 1998 Provisions on the Relevant Issues Concerning the Implementations of Criminal Procedure Law, ${ }^{41}$ offered important support as it was promulgated by six ministries including the SPC, the SPP, the Ministry of Public Security, the Ministry of State Security, the Ministry of Justice and

\footnotetext{
${ }^{40}$ Ibid.

${ }^{41}$ The Supreme People's Court, the Supreme People's Procuratorate, the Ministry of Public Security, the Ministry of State Security, the Ministry of Justice and the Legislative Affairs Commission of the NPC Standing Committee jointly promulgated Guanyu xingshi susongfa shishi zhong ruogan wenti de guiding (Provisions on the Relevant Issues Concerning the Implementations of Criminal Procedure Law) on 19 January 1998, available at: http://www.jincao.com/fa/22/law22.31.htm, accessed on 20 August 2009.
} 
the Legislative Affairs Commission of the NPC Standing Committee. Article 11 blocked early lawyer involvement with the client. Similarly Article 36 of the Ministry of Public Security's Provisions on Public Security Organs in the Procedural Requirements for Criminal Cases ${ }^{42}$ noted that the defendant is entitled to a lawyer but reiterated verbatim the timing of lawyer involvement as stipulated in the CPL Article 96. The same was true for Article 145 of The Regulations of the Supreme People's Procuratorate on Criminal Procedure. ${ }^{43}$

Early lawyer involvement with the client is crucial to the adversarial search for the truth. Unimpeded early lawyer involvement can stand as a correction to “decide first, trial later”. The CPL and its supporting regulations restricted lawyer’s rights on earlier involvement. Moreover, ongoing practice is still prejudicial to the rights of the client. When the lawyer arrives for his first interview with the client at the detention centre he must present the "litigation document" (qi su shu). This document is only prepared by procuratorate after all investigations have been completed. This timing is prejudicial to the gathering of evidence in favor of the client.

The 2007 law envisaged less prejudicial timing so that the lawyer could come to the detention centre and conduct the first interview without the prior approval of investigators. The lawyer need only present his or her practitioner's certificate, the certificate of his or her law firm and the power of attorney, or official legal papers.

Article 47 of the Provisions on the Public Security Organs in the Procedural Requirements for Criminal Cases, however, requires the presentation of an interview notice, issued by Public Security. If the case involved "State secrets", a notoriously loose and

\footnotetext{
${ }^{42}$ The Ministry of Public Security promulgated Gongan jiguan banli xingshi anjian chengxu guiding ( Public Security Provisions on the Procedural Requirements for Criminal Cases) on 14 May 1998, available at: http://www.fire.gov.cn/fg/XZFG/ZL/QT/gz73.htm, accessed at 21 August 2009.

${ }^{43}$ The People's Procuratorate promulgated Renmin jianchayuan xingshi susong guice(Regulations of the Supreme People's Procuratorate on Criminal Procedure), 18 January 1999, available at: http://jpkc.ne.sysu.edu.cn/xsss/law/ssgz.htm, accessed on 21 August 2009.
} 
discretionary category, then Public Security would have to ratify the interview. This requirement was reinforced by Article 96 of the CPL and by Article 150 of The Regulations of the Supreme People's Procuratorate on Criminal Procedure. The 1998 six-ministry provisions, however, referred to the lawyer's ability to meet with the client within the first 48 hours without public security approval provided "state secrets” were not involved.

The lawyer must run the gauntlet to get an appropriately timed interview with his client, but even once the interview takes place, there is another problem, namely, the atmosphere of intimidation surrounding investigator surveillance. Article 33 of the newly amended law reassured the lawyer-client interview would not be subject to surveillance. But again this is challenged in other law and in practice. Article 96 of CPL states: "When the lawyer meets with the criminal suspect in custody, the investigation organ may, in light of the seriousness of the crime and where it deems it necessary, send its people to be present at the meeting." This stipulation was reinforced in the related regulations of public security and the SPP. However, most city detention centers have surveillance cameras in every interview room. The defense is placed in a passive position and is vulnerable to the other side moving the goal posts at a critical initial stage in the proceedings. The lawyer without guanxi faces likely great difficulty in setting up the first interview without the support of the investigators.

The preparation of the lawyer's case for the defense is also complicated with regard to the collection of evidence. The disclosure of evidence has historically compromised the rights of the defense, but Article 34 of the new lawyer law promised lawyer access to all case materials. CPL Article 36 subverts Article 34's intention allowing early lawyer access to the client in that it only allows access "from the date on which the People's Procuratorate begins to examine a case 
for prosecution, consult, extract and duplicate the litigation documents pertaining to the current case and the technical verification material.”

The defense lawyer labors under other handicaps. Article 35 of the 2007 Lawyer Law allowed the lawyer the freedom to collect evidence without procuratorial permission. Article 37 with some qualification sought to strengthen the lawyer's personal rights against specious claims of criminal responsibility. It states:

The personal rights of a lawyer in practicing law shall not be infringed upon. The representation of defense opinions presented in court by a lawyer shall not be subject to legal prosecution, .... Where a lawyer is legally detained or arrested for any suspected criminal involvement during participation in a legal proceeding, the detention or arrest organ shall notify the relative, the law firm and the lawyers' association of the lawyer within 24 hours after the adoption of detention or arrest. ${ }^{44}$

This reassurance, however, really does not really relieve the lawyer of the threat of criminal charges under Article 306 of the Criminal Law. The latter anticipates problems that will attract severe criminal law penalty:

A defender or an agent ad litem who, in the course of criminal procedures, destroys or forges evidence, assists the party concerned in destroying or forging evidence, threatens or lures a witness to, contrary to the facts, change testimony or provide false evidence, shall be sentenced to fixed-term imprisonment of not more than three years or criminal

\footnotetext{
${ }^{44}$ Article 37, Zhonghua renmin gongheguo lushifa (Law on Lawyers of the People's Republic of China). It was amended and adopted at the 30th Session of the Standing Committee of the Tenth National People's Congress of the People's Republic of China on October 28, 2007, and the Law on Lawyers of the People's Republic of China was made effective as of June 1, 2008, available at http://vip.chinalawinfo.com/newlaw2002/slc/slc.asp?db=chl\&gid=98767, accessed on 23 August 2009.
} 
detention; and if the circumstance is serious, to fixed-term imprisonment of not less than three years and not more than seven years. ${ }^{45}$

This article ominously sets up a crime for lawyers only. ${ }^{46}$ It hangs over the lawyer's head like the "sword of Damocles". No wonder that there is "little interest in taking criminal law cases." The defense lawyer may now be able to cite the 2007 law, but the security and investigative authorities have a range of law and organizational tactics to stall the lawyer's defense of his, or her client.

These issues recently came to a head in the riveting controversy surrounding the arrest and sentencing of a Beijing lawyer, Li Zhuang. Li initially acted as defense lawyer for one of the leaders of organized crime in Chongqing, Gong Gangmo. Gong faced serious accusations of murder, illegal weapons trade, drug dealing and heading a criminal organization. The national media focused attention on the Chongqing anti-crime campaign, but the rapid and fierce blows dealt organized crime have raised questions about extraordinary procedural abuses by Chongqing public security.

On 10 December 2009, Gong reported to the police that his lawyer urged him to fake evidence that he had been tortured. Li was arrested two days later. Gong claimed that he turned in his lawyer so as to avoid the death penalty. The Chongqing media and incensed public opinion cast $\mathrm{Li}$ in the role of a wicked wealthy lawyer who profited enormously from rescuing "heinous

\footnotetext{
${ }^{45}$ Article 306, Zhongguo renmin gongheguo xingfa (Criminal Law of the People's Republic of China), Adopted by the Second Session of the Fifth National People's Congress on July 1, 1979, amended on March 14, 1997 and made effective from October 1, 1997. available at http://www.szxingshi.com/95w9.html, accessed on 21 August 2009.

${ }^{46}$ All China Lawyers Association, Xin lushifa jinqi shishi lushi gaodu guanzhu di 33 tiao de luoshi (New Lawyer's Law comes into effect today, the lawyers are paying attention to the implementations of Article 33), 2 June 2008, available at: http://www.zzsf.gov.cn/lvnew/printpage.asp?ArticleID=104, accessed on 10 august 2009.
} 
criminals” from the long arm of the law。 ${ }^{47}$ Chinese newspapers dubbed the case, "Lawyer fakegate”. 48

Li had wanted all of China’s lawyers to stand up in his defense. Some did but more for the sake of general principle. On 17 December 2009, twenty more lawyers added their names to a petition to the NPC calling for the review of legal procedure relating to the Chongqing crackdown on organized crime. Their petition highlighted Articles 33 and 34 of the 2007 lawyer’s law indicating: “...the undersigned lawyers claim that the Chongqing public security is involved in infringement of the lawyer's defendant meeting rights, the right to review litigation documents and the abuse of law and the infringement of fundamental legal procedure.” 49

On December 29, a seminar at Beijing's Law and Politics University that included eminent jurists such as Zhao Bingzhi and He Bing focused on the implications of Li's case for the defense lawyer rights as embedded in the 2007 lawyers' law. ${ }^{50}$ Zhao questioned the two main points in the procuratorate's case. Advice on the issue of torture would have been within the rights of the defense lawyer. Secondly, procuratorial suggestion that $\mathrm{Li}$ had leaked the confidential details of another client's case to Gong would seem unlikely as Public Security officials were present during Li’s meetings with Gong.

\footnotetext{
47 "Lawyer's Trial in Chongqing Rivets Public and Tests Chinese Courts," available at: www.insideoutchina.com/2010/01/lawyers-trial-in chongqing-rivets.html, accessed on 25 January 2010.

${ }^{48}$ See Reuters news article by Ben Blanchard, available at: http://af.reuters.com/article/worldNews/idAFTRE6070PK20100108, accessed on 25 January 2010.

${ }^{49}$ See "20 yu lushi lianming shang shu renda changweihui cheng Chongqing da hei cun weifan lushifa xingwei,” (Twenty more lawyers sign petition to NPC Standing Committee claiming the lawyers' law has been infringed in Chongqing's crackdown on organized crime), available at: http://bbs.366tian.com/redirect.php?tid=1050702\&goto=lastpost, accessed on 25 January 2010.

50 "He Bing,He Weifang, Zhang Sizhi zhi deng Beijing faxue mingjia yantao Li Zhuang an”, (Famous Beijing jurists including He Bing, He Weifan, Zhang Sizhi and others meet to discuss the Li Zhuang case), Center of Public Decisions Research, University of Political Science and Law", available at: http://www.mylegist.com, 5 January 2010, accessed on 25 January 2010.
} 
There was also foreign criticism of the failure to call any witnesses including Gong Gangmo violated CPL Article 47 which stipulates: "The testimony of a witness may be used as a basis in deciding a case only after the witness has been questioned and cross-examined in the courtroom by both sides." 51 Zhao Bingzhi did not address Li’s own concern that according to the lawyer's law public security should not have been in the room at all. The court denied Li's request to see the tape of his interview with Gong. The Beijing professors were concerned that there was little real confirmation of Li's attempt to advise Gong to lie about his treatment except for speculation that he had winked his eyes. In short, the evidentiary standard in the case utterly lacked rigor.

The University of Political Science and Law meeting used the attack on Li to discuss the unhealthy trend to misappropriate Article 306 in the Criminal law regarding lawyer fabrication of evidence. Zhao noted that 90 per cent of the cases tried under this provision had resulted in acquittal. In effect Article 306 is a bad Article that damages the judicial system.

The Li Zhuang case raised an important issue of procedural justice; however, Li, did not fare well. Apparently an initial deal fell through, and in his February 2010 trial of second instance, Li pleaded guilty, was sentenced to one and half years under Article 306 and lost his lawyer’s license.

\section{The NPC and the Prospect for Consistency}

The relevant lines of jurisprudential debate have become clearer in light of a formal request in the summer of 2009 by He Yue of the Chinese People's Political Consultative Conference to the NPC Standing Committee. He raised five issues highlighting the tension between the 2007 amended Lawyer's Law and the 1996 CPL and supporting regulation. He

\footnotetext{
51 “Li Zhuang’s Conviction and the Problem of Witnesses”, Donald Clarke, Blog Editor, Chinese Law Prof Blog, A Member of the Law Professor Blogs Network, 8 January 2010, available at: http://lawprofessors.typepad.com, accessed on 20 January 2010.
} 
wanted NPCSC remedy. Some jurists had argued that the CPL took precedence over the former as it is a basic law, passed by the entire NPC; however, argument that the 2007 law reflected the latest thinking in judicial reform won the day.

In its "reply" (dafu) to He Yue, the NPCSC addressed each of He's five original concerns. $^{52}$ Firstly, the NPC clarified its support for the precedence of the Lawyers' Law with respect to the timing of lawyer access to the client. The NPC preferred access as of the date of the first interrogation. This issue had been covered in the national media with regard to a case of a Shanghai lawyer denied access to his client in Henan by prison authorities who adhered to the precedence of the CPL

Secondly, the NPC reiterated that once the lawyer meets the client, as provided in the 2007 law, there must be no form of official surveillance. Thirdly, the NPC dealt with lawyer access to evidence. While the CPL allowed only access to, and duplication of "judicial materials” that were held by the judge but had been pre-selected by the procuratorate, the 2007 law gave the right of access and duplication with regard to all the file materials held by the procuratorate. Congress accepted that the lawyer could gain access to material that the procuratorate did not deem useful to the prosecution, but which could possibly serve the interests of the defense.

Fourthly, the NPCSC agreed that the 2007 law exempted the lawyer from the CPL constraints requiring pre-authorization for the investigation and collection of evidence. Access and collection of all evidence was now based exclusively on the presentation of a valid lawyer's practicing certificate and certificate of his or her law firm. Finally, the NPCSC supported the

\footnotetext{
${ }^{52}$ Legal Work Committee, National People’s Congress Standing Committee, Dui zhengxie shiyi jie quanguo we yuan hui di yi ci huiyi di 1524 hao (zhengzhi falulei 137 hao) ti an de dafu, (Reply to politics and law proposal 137 from the Chinese People’s Political Consultative Conference Session 1524), (15 August 2009).
} 
Lawyers Law on ensuring the lawyer's protection against criminal law prosecution under the widely criticized Article 306.

An NPCSC “reply” does not have the standing of legislative interpretation, but it indicates the NPC's prevailing frame of reference. Up until the NPC decides to act, there are significant contradictions in law that militate against the new lawyer's law. Passive aggressive bureaucratic resistance to the amended lawyer's law is continuing to make selective use of the contradictions in the law.

\section{Conclusion:}

Until recently, China did not have any "lawyer" system at all. It must be stressed that the lawyer is a new "species” in China. Moreover due process has had to be learned during a crash program for procedural reform in a context of heady socio-economic change and bureaucratic resistance. The defense lawyer is vulnerable to the erratic vicissitudes of changing law and politics, but the cause of lawyer reform is not necessarily lost. The public reaction to the $\mathrm{Li}$ Zhuang case suggests a newly emerging culture within the legal circles that is prepared to protest vigorously the violation of the 2007 lawyers' law by public security.

The question arises what will the NPC do? The NPCSC has signaled that it regards the 2007 as superior to the CPL. The Chinese lawyers system is part of a wider progression of legal reform that is, itself, a subset of a huge experiment in socio-economic change that anticipates

constant contradiction. Legal reform has responded with a growing formal commitment to a new balance of values that underwrites the a priori objectives of Chinese society and culture while supporting the lawyer's professional protection of client rights and interests. Amendment to the lawyer law characterized the lawyer as a professional who has rights to defend his or her client. There is enormous political pressure on China's judicial system to vindicate itself by 
taking bold and even extra-legal measures in eliminating corruption; however, the issue over the abuse of Article 306 is heating up, and the NPCSC has publicly indicated that the 1996 CPL and concomitant security and investigator regulations have fallen behind the reform initiative that produced the 2007 lawyer's law.

The defense lawyer in China today still faces tremendous institutional hurdles, but the formal appearance of the lawyer qua "lawyer" has already become a remarkable episode in the annals of Chinese legal history. In practice, the progressive tying of professionalism with the legal protection of the rights of lawyers and their clients is still controversial as the Party has focused on "judicial democracy" and on the campaign against corruption so as to foster "harmony" and to respect the "feelings of the people". The people and it naturally follows, the Party may be more interested in punishing criminals rather than looking after their rights. On the other hand, the lawyer profession, itself, has a growing stake in the defense of the revised lawyers' law as against the older provisions of the CPL. The law firm is now operating within a new market context, and the lawyer is not going to return willingly to the status of a "state worker”.

If prevailing culture reflects a deep belief in law and order as based on the deterrence of criminal law punishment, reform has, nonetheless, been able to nurture lawyer and client rights and interests. The above discussion of the 2007 lawyer reform suggests how things can simultaneously move in opposite directions in China, the deep complexity of change, the very real complications of recalcitrant practice in organizational and conceptual continuity and how there is sometimes more Chinese agreement with international norms and "world trends" than what is expected in sometimes less than nuanced international reporting. 